\title{
Genetic variability for temporal polyethism in colonies consisting of similarly-aged worker honey bees
}

\author{
W.C. Rothenbuhler and R.E. Page Jr * \\ The Ohio State University, Department of Entomology, 1735 Neil Ave., Columbus, OH 43210, USA \\ (received 8 February 1989, accepted 30 August 1989)
}

Summary - Behavioral studies of 2 selected lines of honey bees (Brown and Van Scoy) demonstrate strong genetic determination of individual differences in behavior. Bees of similar age, but of different lines, performed tasks with very different frequencies. Brown workers performed mostly within nest tasks while Van Scoy workers did most of the foraging. It is suggested that the genotypic composition of a colony represents a level of social organization.

Apis mellifera - polyethism - genetic variability

\section{INTRODUCTION}

The currently accepted model of division of labour in insect societies minimizes the role of the genotype of an individual as a determinant of the observed variability of behaviour among nestmate workers (Oster \& Wilson, 1978). Instead, variability in behaviour is assumed to be a consequence of physical-caste membership, age polyethism, and individual plasticity of behaviour (Wilson, 1985). This model has been applied to honey bee (Apis mellifera L.) societies where it is assumed that individual workers progress through a series of more or less discrete temporal-castes where the probabilities for performing specific sets of tasks change with age and colony requirement (see Seeley 1982, 1985 and Winston, 1987 for reviews of division of labour in honey bees). Variability in the rates at which individuals change temporal castes, and variability in the frequency at which an individual performs a given task within a temporal caste, are determined epigenetically. Colony-level adjustments to caste-structure are also assumed to take place in response to changes in environmental stimuli; such as those associated with brood or foraging resources, and age structure.

Calderone \& Page (1987) demonstrated that the genotype of a honey bee

\footnotetext{
${ }^{*}$ Correspondence and reprints.
} 
worker influences both the probability of performing specific tasks and also the age at which she makes the transition from within-nest tasks to foraging (see Seeley, 1982; Winston \& Katz, 1982; Kolmes, 1985). Robinson \& Page (1988, 1989) demonstrated the effect of the genetic structure of honey bee colonies, resulting from polyandry (see Page, 1986 for review of polyandry in honey bees), on social organization. They showed that members of different sub-families (members of the same sub-family share the same mother and father) within normally-functioning colonies have different sets of probabilities of engaging in specific tasks. In this paper we report genotypic effects on the behaviour of same-aged individual workers maintained in small colony units.

\section{MATERIALS AND METHODS}

Two small colonies were established in observation hives located within a shelter. Each colony was initiated with a queen and 400 individually-distinguishable, paint-marked workers that had emerged within the previous $48 \mathrm{~h}$ from combs maintained in an incubator. Previous studies have demonstrated that colonies established in this manner demonstrate a division of labour despite the abnormal size and age structure (Nelson, 1927). Colony 1 (the West colony) was established on 13 August 1969 with 200 workers from each of the Brown and Van Scoy genetic lines that were maintained at The Ohio State University (see Rothenbuhler, 1964a, $1964 \mathrm{~b}$ for discussion of these lines). On $11 \mathrm{Sep}-$ tember, 200 additional unmarked young workers (100 Browns and 100 Van Scoys) were added. Colony 2 (the South colony) was established on 16 August 1969 with 200 workers from the Brown line and 200 hybrids from a cross of the Brown and Van Scoy lines. These 2 lines differed in at least 2 behavioural characteristics : the Brown line was hygienic (uncapped and removed dead brood) and defensive, while the Van Scoy was non-hygienic and indefensive.
The entrance of each colony opened into separate $3 \mathrm{~m} \times 3 \mathrm{~m} \times 6 \mathrm{~m}$ screen cages. Workers were trained (Wenner, 1961) on 2 September and 6 September (for West and South colonies, respectively) to forage for sugar syrup and pollen at a table located in the middle of each cage. Daily observations and counts were made between 9-11 September for the number of marked workers of each line in the West colony that : i) collected syrup during 65 total min of observation; ii) flew off from a comb that was removed from the colony during examination (considered a defensive behaviour); and iii) removed freshly killed or diseased larvae from cells during examination.

On 6 and 7 September, observations and counts were made of marked workers from the South colony that : i) entered the hive with pollen loads during 25 min of observation; ii) collected pollen from a dish during 19 instantaneous counts, and iii) collected sugar syrup from a dish during 4 instantaneous counts. Censuses of remaining marked individuals of each line were taken daily. An additional 349 (approx) young bees raised in the colony were present during the census of 6 September. All data were analyzed with $2 \times 2$ contingency tables (Sokal \& Rohlf 1981).

\section{RESULTS}

Similarly-aged, but genetically different workers performed different tasks. Genotype, in addition to age and colony need, contributes to division of labour among workers. On 9 September, 124 Browns and 66 Van Scoys survived in the West colony. Of 141 observations of marked bees collecting syrup on 9 and 10 September, 130 were $\operatorname{Van}$ Scoy workers $(P<$ 0.01 ). For 34 observations of marked bees flying off from the comb during inspection, 32 were Browns $(P<0.01)$, while 28 out of 33 observations of cell-cleaning activity were of bees from the Brown line $(P<$ $0.05)$. Observations of September 20-22 for the West colony and observations of 
the South colony show the same trend: individuals from the Brown line performed the within-nest tasks of defense and cell cleaning while the Van Scoys and $F_{1}$ hybrids foraged (Fig. 1).
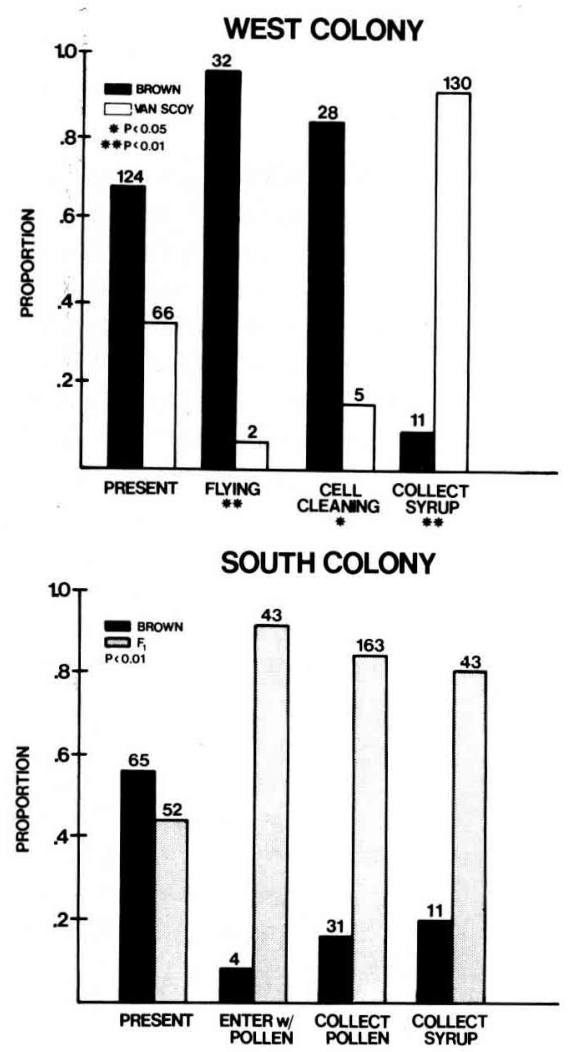

Fig. 1. The partitioning of tasks between cohorts in the West and South colonies. The number of individuals belonging to each line that were PRESENT in each colony was determined by averaging 2 separate approximate counts taken on separate days of observation. Proportions of individuals belonging to each line observed performing each task are presented. The actual counts for each task are presented at the top of each bar. Data for the West colony are from observations of September 20-22, only. * = statistical analysis is significant at the 0.05 level; ** = significant at 0.01 . All comparisons were significant.

\section{DISCUSSION}

Even though these colonies were atypical, the results demonstrate a genetic component to individual variability in temporalcaste changes that are due to environmental stimuli. In this case, the demographic structure of colonies was severely disrupted. Each colony consisted of very small, discrete age cohorts. In response to this disruption, bees of the same chronological age performed tasks which would normally be performed by bees of different ages.

The effects of colony-population size, age structure, and food stores on the age and rate at which workers change tasks have been demonstrated by other investigators (see Seeley, 1985 and Winston, 1987 for reviews), however, the role of genotype has for the most part been ignored. The determination of the behaviour of individual workers in response to what we assume are extreme environmental stimuli, was primarily genotypic in this study. These results, along with those of Moritz \& Southwick (1987), Calderone \& Page (1987), and Robinson \& Page (1988, 1989) emphasize a newly-recognized level of colony organization-namely social genetics.

\section{ACKNOWLEDGMENTS}

This investigation was suppported in part by PHS Research Grant HD-00368-04 from the National Institute of Child Health and Human Development to WCR. We thank Miss Sharon Brooks for her participation in this research. Experimental design and data collection were by W.C. Rothenbuhler. Data analyses and manuscript preparation by R. E. Page. 
Résumé - Variabilité génétique de la division du travail au cours du temps dans des colonies d'abeilles dont les ouvrières ont le même âge. On a constitué 2 colonies d'abeilles comportant chacune une reine et 400 ouvrières marquées et âgées de moins de $48 \mathrm{~h}$. Les ouvrières de chaque colonie provenaient de 2 souches sélectionnées (Brown et Van Scoy), qui différaient l'une de l'autre par leur comportement hygiénique et leur comportement de défense (par ex. ouverture et nettoyage des cellules de couvain renfermant des larves malades). On a étudié le comportement des ouvrières de chaque souche dans chaque colonie. Les abeilles de même âge, mais de souche génétique différente accomplissaient des travaux donnés avec des fréquences très différentes. Les ouvrières de la souche Brown étaient surtout actives à l'intérieur de la ruche (désoperculation des cellules et retrait des larves), tandis que les ouvrières de la souche $V$ an Scoy et les filles $F_{1}$ de la reine Brown accomplissaient la plus grande partie de la récolte de nectar et de pollen. Les dénombrements représentés dans les figures ont été réalisés environ 4 semaines après la constitution de la colonie; les chiffres indiqués dans les 2 premières colonnes ("Present") représentent les abeilles marquées encore présentes; les colonies avaient été renforcées entre temps. On estime qu'outre l'âge, la composition génotypique d'une colonie représente un niveau d'organisation dans les sociétés d'abeilles.

\section{Apis mellifica - polyéthisme - variabi- lité génétique}

Zusammenfassung - Genetische Variabilität der altersabhängigen Arbeitsteilung in Völkern mit Arbeitsbienen ähnlichen Alters. Es wurden 2 Bie- nenwölker eingerichtet, von denen jedes eine Königin und 400 markierte Arbeiterinnen im Alter von weniger als 48 Std aufwies. Die Arbeiterinnen jedes Volkes stammten aus 2 selektierten Linien (Brown und Van Scoy), die sich im Hygiene- und Verteidigungsverhalten unterschieden (z.B. Öffnen und Reinigung von Brutzellen mit kranken Puppen). Bei jedem Volk wurde das Verhalten der Arbeiterinnen aus jeder Linie untersucht.

Bienen ähnlichen Alters, aber aus verschiedener genetischer Linie führten bestimmte Arbeiten mit sehr unterschiedlicher Häufigkeit aus. Arbeiterinnen der Brown-Linie waren hauptsächlich mit Aufgaben im Stock beschäftigt, wie Öffnen von Zellen und Entfernen von Larven, während die Arbeiterinnen der Van ScoyLinie und die $F_{1}$-Töchter der BrownKönigin hauptsächlich Nektar und Pollen sammelten. Die in der Abblidung dargestellten Zählungen wurden etwa 4 Wochen nach Bildung der Völkchen durchgeführt; die in den ersten beiden Säulen angegebenen Zahlen ("Present") geben die Zahlen der noch vorhandenen markierten Bienen an; die Völkchen waren inzwischen verstärkt worden. Es wird vermutet, daß neben dem Alter auch die genotypische Zusammensetzung eines Volkes einen bestimmten Organisationsgrad in BienenSozietäten darstellt.

Apis mellifera - Polyethismus - genetische Variabilität

\section{REFERENCES}

Calderone N.W. \& Page R.E. (1987) Genotypic variability in age polyethism and tasks specialization in the honey bee, Apis mellifera (Hymenoptera : Apidae). Behav. Ecol. Sociobiol. 22, $17-25$ 
Kolmes S.A. (1985) A quantitative study of the division of labour among worker honey bees. $Z$. Tierpsychol. 68, 287-302

Moritz R.F.A. \& Southwick E.E. (1987) Phenotypic interactions in group behaviour of honey bee workers (Apis mellifera L.). Behav. Ecol. Sociobiol. 21, 53-57

Nelson F.C. (1927) Adaptability of young bees under adverse conditions. Am. Bee J. 67, 242243

Oster G.F. \& Wilson E.O. (1978) Caste and Ecology in the Social Insects. Princeton University Press, Princeton, NJ, USA

Page R.E. (1986) Sperm utilization in social insects. Annu. Rev. Entomol. 31, 297-320

Robinson G.E. \& Page R.E. (1988) Genetic determination of guarding and undertaking in honey-bee colonies. Nature 333, 356-358

Robinson G.E. \& Page R.E. (1989) Genetic basis for division of labour in an insect society. In : The Genetics of Social Evolution (Breed M.D. and R.E. Page, eds) Press, Boulder, pp. 61-80

Rothenbuhler W.C. (1964a) Behaviour genetics of nest cleaning in honey bees. I. Responses of four inbred lines to disease-killed brood. Anim. Behav. 12, 578-583
Rothenbuhler W.C. (1964b) Behaviour genetics of nest cleaning honey bees. IV. Responses of $F_{1}$ and backcross generations to disease-killed brood. Am. Zool. 4, 111-123

Seeley T.D. (1982) Adaptive significance of the age polyethism schedule in honey bee colonies. Behav. Ecol. Sociobiol. 11, 287-293

Seeley T.D. (1985) Honey bee Ecology. Princeton University Press, Princeton, NJ, USA

Sokal R.R. \& Rohlf F.J. (1981) Biometry. Freeman, N.Y., USA

Wenner A.M. (1961) A method of training bees to visit a feeding station. Bee World 42, 8-11

Winston M.L. (1987) The Biology of the Honey Bee. Harvard University Press, Cambridge, MA, USA

Winston M.L. \& Katz S.J. (1982) Foraging differences between cross-fostered honey bee workers (Apis mellifera) of European and Africanized races. Behav. Ecol. Sociobiol. 10, 125-129

Wilson E.O. (1985) The principles of caste evolution. In : Experimental Behavioral Ecology and Sociobiology (B. Hölldobler and M. Lindauer, eds) Sinauer Assoc. Inc., Sunderland, 307-324 